\title{
Notes from NOREF and İhsan Doğramacı Center for Foreign Policy and Peace Research: Summary and Reflections on the Turkish and Norwegian Approaches to the Arab Spring and Peacebuilding*
}

\author{
Ç. Esra Çuhadar \\ Bilkent University \\ Monica Rafael Simoes \\ Norwegian Peacebuilding Resource Center (NOREF)
}

The Arab uprisings and the transition processes following the regime changes in these countries have occupied the foreign policy agendas of Turkey and Norway during the last two years, even though these events affected the two nations in varying degrees and ways. Turkey, as a direct or regional neighbour of these Arab countries, has been experiencing this process more directly and has been greatly affected economically, socially, and politically, especially from the influx of almost 200.000 refugees. Norway, on the other hand, which has been experiencing this process rather indirectly and from a greater distance, has still been impacted in a variety of ways. Regardless of the magnitude of the tremors felt by Turkey and Norway, both countries desire to act upon the developments in a constructive manner and be constructive forces to help this transition. A Turkey-Norway collaboration may sound like an unusual partnership, but a common agenda for peacebuilding and conflict resolution led two organizations, the Norwegian Peacebuilding Resource Center (NOREF) and the İhsan Doğramacı Peace Foundation's Center for Foreign Policy and Peace Research at Bilkent University in Ankara, to explore the potential of this partnership in relation to the Arab uprisings. The two groups collaborated in a workshop held with Turkish and Norwegian academics under the co-sponsorship of the Strategic Research Center (SAM) of the Turkish Ministry of Foreign Affairs on 1 and 2 November 2012 in Ankara. The workshop focused on the Arab uprisings from a peacebuilding and conflict resolution perspective. Presenting the views anonymously, this article summarizes and reflects on some of the discussions held during the workshop.

Turkey is increasingly becoming a relevant actor in global politics and strongly attractive to its neighbours in the Arab world. Several factors have made this possible: Turkey's geographical location and unique historical ties with regional countries; its inspiring growing economic successes in maintaining financial stability, attracting foreign direct investment, and increasing exports worldwide; and its successful democratic reforms implemented in the last decade (such as in the area of civil-military relations) that have contributed to its emergence as a stronger democratic power. This reform process has also been reinforced by

C.. Esra Çuhadar, Asst. Prof. Dr. Department of Political Science, Bilkent University. E-mail: esracg@bilkent.edu.tr. Monica Rafael Simoes, Adviser, Norwegian Peacebuilding Resource Center (NOREF). E-mail: monica.rafael@peacebuilding.no.

"This article summarizes and reflects upon the discussions held at the workshop, titled "Turkish and Norwegian Approaches to the Arab Uprisings and Peacebuilding", without making specific attributions to any person. The views presented here also do not necessarily represent any consensus or agreement. We would like to thank all participants for sharing their views. Needless to say, we claim full responsibility for the content and any mistakes in this article. 
the accession negotiations that Turkey has been conducting with the European Union (EU) since 2005. Turkey's economic and political transformations are reflected in its increasingly active and wide-ranging foreign policy. Thus, as an emerging power, Turkey has begun taking on increasing responsibilities at regional and global levels, including the role of mediator and offering development assistance in many conflicts in neighbouring regions.

Norway's own set of values and norms make it a worldwide celebrated model of democracy and balanced economic development. This country also has a social pact and welfare state model that has been the outcome of a political dialogue among actors with different interests. Norway engages closely with the EU's values and ideas and has strong alliances with the United States (US) and the North Atlantic Treaty Organization (NATO), whilst simultaneously developing an independent and engaged foreign policy promoting national interests and contributing to a more equitable and just world. With a strong tradition of cooperation with and support to the so-called Global South, Norway participates in and promotes processes of negotiation, dialogue, and reconciliation in a series of countries. Currently, Norway is interested in playing a relevant role in efforts leading to the democratization of the Middle East and North Africa (MENA) region.

The workshop explored and analyzed the potential role of Norway and Turkey in the transition processes in Arab societies. In this context, the sessions comparatively discussed the mediation and conflict resolution approaches of the two countries; considered the challenges of reconciling peace, justice, and security and development needs; reflected upon the potentially different consequences and needs of violent and non-violent transitions in Arab societies; and discussed Turkish experiences in democratization as possible references for Arab transitions. The next section will focus on each of these thematic issues.

\section{On Mediation and Peacebuilding}

Mediation is one of the conflict resolution and foreign policy tools that Norway and Turkey both attribute great importance to. Norway has long been credited around the world for its mediation activities in the Middle East, South America, and Asia. Similarly, Turkey's mediation efforts during the last decade have made it one of the most visible actors in the international arena today. Regarding this topic, the discussions addressed the characteristics, power, resources, and impartiality of mediators and the timing of mediation.

Turkey and Norway are both easily seen as facilitators in mediation processes because they emphasize inclusiveness of all actors, dialogue for all, and are able to apply a multidimensional approach. They also refrain from using "muscle" in mediation, a model closely associated with the superpowers, and instead mostly rely on soft power capacities such as development aid and economic assistance.

Although Turkey's mediation efforts before the Arab Spring have not produced conclusive and flashy success stories, they certainly facilitated the process of communication between various disputants and created the image of a constructive power in the Middle East. However, very recently, Turkey's official policy of inclusive dialogue and participation, has suffered challenges and Turkey is now often accused of having lost its mediating leverage in the region because of depreciations in its impartiality (i.e. broken relations and ties with Israel after the flotilla incidence; strained relations with Syria due to the conflict in this country; criticisms articulated by liberal and secular factions in Egypt and Iraq for pursuing a Sunni or sectarian agenda). Despite these criticisms, Turkey continues to be eager to invest in increasing its civilian capacities for mediation. 
Turkey's mediation contributions thus far should perhaps be viewed as contributions to the "process" rather than to the "outcome." Turkey has had a very active role in several mediation initiatives, such as Israel-Syria, Iran and the West, the Balkans, Lebanon, Iraq, Somalia, the Philippines, and Sudan. Changes in the international system, regional demands, and decision-makers' (i.e. AKP and Foreign Minister Ahmet Davutoğlu's) policy agendas have naturally informed Turkey's mediation role and choices. During the last several years, Turkey has also contributed immensely to making mediation a more effective tool within the UN system. Towards this end, it has taken a leadership role in initiatives within international institutions (i.e. founding the Friends of Mediation group, UN General Assembly resolution on mediation, UN Secretary General's report on mediation, and the releasing of the 'Effective Mediation Guidelines 2012' by the United Nations). In terms of the values Turkey brings into mediation, a suggestion was made to call Turkey an "insider mediator"; meaning that although Turkey is not within the parties, it is a third party that intimately knows the region's cultural codes and frames of reference. In this sense, Turkey's model for mediation was considered different from the "impartial mediator" model adopted by Norway.

Norway's mediation activities are always dependent on an invitation from a party to a conflict, and it aims for agreement to be reached by the parties rather than for a solution "mediated" by a super power (i.e. US role in the case of Bosnia). At the same time, Norway maintains its own views and principles in the processes to which it is invited to take part in. Its well-known policy of inclusive dialogue does not mean recognizing or legitimizing all parties, but rather presenting an understanding that such a dialogue will be the key to longterm commitment to the process and peaceful settlement. In this sense, Norway and Turkey hold similar positions towards parties in conflict. Norway is also known as a "team player" in peacebuilding, in that it often cooperates and coordinates with other countries and third parties in peace processes.

Given these similarities and differences in their approaches to and capacities for mediation, can the two countries cooperate in dialogue and mediation activities in global conflicts? Participants highlighted how the similarities and differences might contribute to or detract from successful outcomes.

Similarities could trigger cooperation between the two countries: both are close to, though outside of, the EU, with a great level of independence in their foreign policies, which are nonetheless framed within NATO dynamics. Both countries are experienced in engaging in conflict situations as third parties and in high-level engagement in many different situations. Finally, there is a shared common interest to contribute to peaceful resolutions of conflicts and tensions, especially in the Middle East.

Differences among both actors should also be taken into consideration. The positions of the two countries vis-à-vis the transitions in the Middle East are not very clear at the moment. Whilst Norway is perceived as an outside and distant observer with interests in the region (shipping, oil, other economic interests) and a major financial promoter of the UN, Turkey has an urge to act as a third party and a need for closer engagement in and ties for promoting democracy and peaceful transitions in the region (whether it will be able to move forward on this remains to be seen). That social change and conflict resolution involve different dynamics and require different approaches was identified as a challenge for both countries' desires to operate in the region. The attitudes of the two countries about this natural dilemma and how they tackle it have yet to emerge. 
Some concerns about such cooperation between Norway and Turkey were also put forward, namely how to overcome various differences; how to harmonize different potential visions of the international order; and how to reconcile long-term projects in a rapidly changing international environment.

Concerns were also raised regarding identifying legitimate parties to talk to and engage with in a conflict. Who is "legitimate" changes according to a country's history and dynamics (e.g. Israel-Palestine; South Africa). Questions on whether such efforts should always be related to impartiality (i.e. possibly legitimizing oppressors or criminals) were discussed. Differences between mediation and third-party intervention (e.g. NATO in Libya) were highlighted. Arguments that some parties to a conflict are not legitimate (e.g. Assad's regime) and thus should not be engaged in mediation activities, versus that all parties to a conflict should be supported, were also put forward. In the latter case, mediation could be brought in later, for example, during the process of transitional justice.

\section{Turkey and the Arab Uprisings}

Turkey is assuming an increasingly relevant role in global politics and economics and has become of great interest to its neighbours in the Arab world. The country has adopted greater responsibilities at regional and global levels, including the role of mediator and broker in many conflicts in neighbouring regions.

Turkey's foreign policy before the Arab Spring was presented as one of "zero problems with neighbours" and pursued stronger economic and political relations with neighbouring countries. The objectives were to become an attractive force and align its interests with those of the region (prosperity and stability), mainly by means of soft power. At the same time, before the Arab uprisings, Turkey was identified overall as a model for the region, appealing to a varied set of actors: whilst some emphasized the richness of Turkish secularism, others stressed its close relations with the West, and still others praised how the Turkish Islamist movement was evolving in a democratic manner.

At present, with the civil war in Syria escalating, relations with Israel coming to a halt, paralyzing disagreements with the Iraqi central government, the collapse of the TurkishArmenian protocol ratification process, etc., Turkey's zero-problems policy is facing challenges. Instead, an emphasis on balancing security and democracy or peace seems to have emerged. Previous to the Arab uprisings, the zero-problems goal was meant to solve bilateral problems, but bilateral relations became entangled and sometimes incompatible with regional dynamics after the Arab Spring. The Turkish model of democracy and harmony thus now faces some limitations, and is not clearly articulated. Does it mean the model of Turkey's ruling Justice and Development Party (AKP), i.e. moderate Islam in domestic politics? Does it embody a model indicating a certain type of state-religion framework? Does it refer to a successful model of economic transformation and growth? Or does it mean a model of democratic consolidation in a predominantly Muslim country?

Turkey as a model is a twofold political (external and internal) discourse: its image as a model for the region combined with a discourse of non-imposition. During discussions in the workshop on lessons learned from the Turkish experience, participants examined the questions posed in the previous paragraph. Some suggested that the Arab uprisings revealed an overestimation of Turkish capabilities and capacities, which has been recently demonstrated in its domestic and foreign policy nexus especially facing the crisis in Syria. 
A major challenge facing Turkish foreign policy in the current regional environment is to resist the strong forces attempting to drag Turkey into regional polarization and sectarian politics and violence. Turkey is trying to overcome them by combining the roles of regional actor and mediator, but the dimensions of its bilateral and regional aims are intertwined or tangled. Thus, the strategic and tactical aspects of this manoeuvre are not straightforward.

\section{Norway and the Arab Uprisings}

Norway has a celebrated model of democracy and economic development, and a strong tradition of cooperation with and support to the Global South.

Norway perceived the underlying causes of the Arab Spring as political and economic, thus leading to its responses based on support to democracy-building and economic development, focusing on the real needs of real people and on a strong engagement with civil society.

The country is interested in playing a relevant role in supporting MENA's democratization, thus it has worked/is working in the region focusing on the issues of political Islam and political stability, youth movements, women's participation in politics, media, religious dialogue, and soft power.

Norway has strong global credibility and is perceived as neutral. As a result, it can play a role in the post-Arab Spring scenario that other Western countries are unlikely to, both in matters of constitutional/political issues (e.g.. providing guarantees to Syrian Alawite minorities) and of transitional justice.

\section{Consequences of the Arab Uprisings}

The Arab uprisings have undoubtedly have led to a shift in the dispersion of power in the region and elsewhere.

Arab politics will undoubtedly be different in the future, hopefully with a greater degree of political participation, and certainly with higher expectations of a better life, of more competitive political systems, and of holding elections that actually reflect the will of citizens at large. The broader trajectory of the revolution implies promises of democracy and competing dynamics in the region. However, fostering/accelerating democracy there is a challenging task that will require time, caution, and profound analysis and knowledge of the dynamics, actors, interests, and politics at stake.

New regional political dynamics will not be the only force to influence politics in that area, however; some legacies will likely persist, such as (i) sectarian and ideological polarization; (ii) the countries' political economies (corruption, informal economies, and other pre-existing structures); and (iii) political clientelism. These legacies will restrict longterm political thinking and intensify regional rivalries (i.e. Syria).

\section{The Challenge of Reconciling Peace, Security, Development, and Transitional Justice}

Peace, security, development, and transitional justice can be engineered in a joint way, as long as national political developments incorporate solving social political struggles. Political consensus and legitimacy must exist. Stability is often seen as a higher priority than legitimacy and consensus, but new actors in politics such as youth in the streets now attribute utmost importance to political legitimacy. These actors highlight establishing consensus in order to maintain a functioning political system and end mass unrest in these societies. 
To achieve peace and security, it is fundamental to reestablish the legitimacy of the state, or in other words, encourage inclusive statebuilding (such as in the case of the Alawites in Syria or the Sunnis in Iraq). Different countries have had very different and rich experiences regarding transitional justice, and in establishing such processes in other countries it would be relevant to look at (i) the substance/transition process roadmap (e.g. Bahrain, Yemen) and (ii) the scope of transitional justice where its ends are a political issue (i.e. Egypt and Libya).

On economic development, some concerns relate to understanding how or whether political economies are reconfigured after a transformation in the region and what opportunities exist for the people who asked for regime change; whether power struggles will result in compromises and institutional power sharing, turning out to be beneficial for longterm development, and determining which factors will make this happen (or not happen); and whether the new political regimes can create stability without reinvigorating the repressive institutions and practices of the past.

When developing policies, grassroots-level and communal groups/actors should be placed at the center of analysis, and local sensitivities must be taken into account. The workshop debate stressed the importance of engaging in strategic dialogue with actors in the field before beginning technical outreach (the need to make normative decisions before technical decisions) and the needs to understand the complexity and consider economic and sectarian perspectives to understand different actors' positions.

Several participants also made reference to the importance of analyzing internal problems in the region from a structural perspective, taking into account postcolonial situations, to avoid the risk of reproducing similar extractive institutions. Participants also noted the lack of experiences with reconciliation and transitional justice in the region and suggested caution about importing external models, such as the South African one.

\section{Key Issues in the Transition}

In analyzing tendencies and actors in MENA, the workshop, examined how, historically, the majority of armed revolutions in Arab states were led against non-democratic governments (e.g. Egypt, Algeria, Syria) and how multiple armed challengers influenced the revolution period and the aftermath. It was stressed that the probability of a country turning into a democracy after an armed conflict is very low and the probability of relapsing into violent conflict is high.

Key determinants of transition are the presence of violence or non-violence in the transition process and how effectively security sector reform (professionalization and depolitization) and demobilization, disarmament, and reintegration (DDR) processes will be carried out. The group discussed the effects of different forms of violence in transitions (e.g. in Tunisia, Syria, and Lebanon) and how sectarian violence is leading to hatred, existential fear, the fragmentation of society, and the isolation of certain minority groups.

In the forthcoming transitions, institution building will be fundamental to ensure that the processes successfully unfold, and to provide people safety and instill confidence. Institutions provide safety because they offer channels to address difficult issues, e.g. decentralization; however, a relevant point was made about the international dearth of knowledge on institution building. Most experience in that area comes from East Asia (i.e. South Korea, where the idea is that strong institution building will lead to a truer democracy), but the context in which Arab uprisings are taking place is very different. 
In terms of cultural transition, protecting the multicultural, multiethnic, and multireligious nature of these societies is crucial for the future of the region. Sacred places are being attacked by extremist groups with the objective to destroy multiculturalism. Without preserving common heritage and symbols of coexistence, it will be difficult for future generations to connect with their culture and recognize and appreciate multiculturalism.

\section{Role of External Actors}

As a consequence of the Arab Spring, there is a continuing decline in external powers' capacity to shape regional affairs. For external actors to become involved in the region, it is fundamental that they examine (i) their legitimacy to act (i.e. what relations they may have had with brutal regimes or repressive non-state actors); (ii) their legacy in the region (if any, i.e. whether they have had a traditionally divisive impact or not, e.g. Russia, the US, the EU); and (iii) past trajectories (e.g. the experience of the Balkans) and the mistakes carried out in them.

The group analysis focused on how a holistic transition in Arab societies will require contributions from other actors (e.g. Iraq, Qatar, Saudi Arabia, Turkey, the US, Russia, the UK) and how the international community should always act responsibly, but specifically post-conflict, i.e., in areas of reconciliation; in ensuring political guarantees to isolated groups (e.g. in post-Assad Syria); in contributing to strengthening civil society; and in assisting with the institution-building process and with establishing interreligious councils. The responsibility of researchers to label situations in a manner that will aptly inform political decision-making was also addressed. 
